\title{
MOLECULAR METHODS FOR DIAGNOSIS OF MALARIA
}

Snehanshu Shukla1, Harshita Pant².

\section{HOW TO CITE THIS ARTICLE:}

Snehanshu Shukla, Harshita Pant. "Molecular methods for diagnosis of malaria". Journal of Evolution of Medical and Dental Sciences 2013; Vol2, Issue 28, July 15; Page: 5194-5205.

ABSTRACT: In PCR based techniques specific regions of DNA are amplified, enzymatically through successive cycles, resulting in million-fold amplification of the target sequence of DNA. PCR can detect cases declared negative by microscopy and mixed infection due to its high sensitivity at low level of Parasitemia (F. Perandin et al., 20041; Gabriella A. Farcas et al., 20042; Stephanine P. Johnston et al., 20063; Monar Ndao et al., 20044).

KEY WORDS: PCR, P. falciparum, P. vivax, RDT, malaria, SS rRNA.

INTRODUCTION: Molecular method can be used as a research tool to perform quality control checks on microscopic diagnosis of malaria. (Brown et al., 19925, Snounou et al., 19936) or to determine the distribution of important genes associated with drug resistance (Klement E et al., 20017, Ciceron et al., 19998, Humar et al., 19979). The limitation of the PCR technique includes considerable time required for processing, requirement of experience, instrumentation and technical expertise (Robert H. Barker et al., 199410). Selection of appropriate primers, method used for collection and storage of samples and extraction methods can all affect PCR performance. Inspite of this increasing PCR is being coated as the "new gold standard" for diagnosis of malaria (Haditsch, 200411; Ndao et al., 20044).

Molecular Diagnostic Assay

In 1984 Franzen et al. ${ }^{12}$ reported the isolation and characterization of a repetitive DNA probe to identify $\mathrm{P}$. falciparum infected blood in a spot hybridization assay. The identified recombinant clone contained a $21 \mathrm{bp}$ tandemly repeated sequences that was specific for $\mathrm{P}$. falciparum. Further studies using it found to be very specific for P. falciparum but sensitivities parallel that of microscopic examination only in best circumstances. Difficulties in the detection of low Parasitemia in partially immune individuals from malaria endemic areas were particularly noted, as is the situation of India. An effort focused on the detection of plasmodial ribosomal RNA provided sensitivity significantly better than that of repeat-based DNA probes.

PCR

PCR based assays represent a major advance for the laboratory diagnosis of malaria and also have a variety of other research applications (Table R-1).

Advantages of PCR

1. Ability to detect as few as $1-5$ parasites/ $\mu$ l of blood $(<0.001 \%$ of infected red blood cells.

2. Large number of samples can be processed at the same time

3. Ability to detect mixed species infections 
Table R-1: Applications of molecular amplification methods for the diagnosis and management of malaria

- Clinical situations:

- Subpotent Parasitemia associated with chemoprophylaxis or diagnosed during the convalescent period.

- Diagnosis of mixed infections

- Therapeutic monitoring and prediction of treatment failure

- Research settings

- Prevalence studies in mainly asymptomatic populations

- Antimalarial efficacy trials

- Vaccine trials

- Reference standard for the evaluation of other non-microscopy methods (e.g. immunochromatographic assays)

- Genotype characterization and molecular epidemiology

The sequence of the oligonucleotides used in majority of the PCR assays is based on the small subunit rRNA gene of plasmodium species that infect human (McCutchan et al., 198813). The PCR protocol based on the other oligonucleotide sequences are described in TableR-2:

Table R-2: Examples of Different protocols used for PCR assays.

\begin{tabular}{|c|c|c|}
\hline $\begin{array}{l}\text { Amplification } \\
\text { Method }\end{array}$ & $\begin{array}{l}\text { Target used for detection and differentiation } \\
\text { of Plasmodium species }\end{array}$ & Used by \\
\hline \multirow[t]{4}{*}{ Single step PCR } & $\begin{array}{l}\text { Small subunit ribosomal RNA gene (SS rRNA } \\
\text { gene) }\end{array}$ & 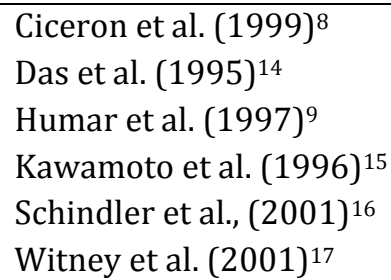 \\
\hline & K1-14 gene & Zhong et al. (1999) ${ }^{18}$ \\
\hline & Circumsporozoite protein gene & Serhabur et al. $(1992)^{19}$ \\
\hline & Erythrocyte binding antigen (EBA-175) & Kain et al. (1991) 20 \\
\hline \multirow[t]{3}{*}{ Nested PCR } & Merozoite surface antigen (MSA) gene & Edoh et al. $(1997)^{21}$ \\
\hline & Erythrocyte binding antigen (EBA-175) & $\begin{array}{l}\text { Eoley et al. }(1992)^{22} \\
\text { Kain et al. }(1991)^{20}\end{array}$ \\
\hline & SS rRNA gene & $\begin{array}{l}\text { Ciceron et al. }(1999)^{8} \\
\text { Kawamoto et al. }(1996)^{15} \\
\text { Schindler et al., }(2001)^{16} \\
\text { Witney et al. }(2001)^{17}\end{array}$ \\
\hline \multirow[t]{2}{*}{ Multiplex PCR } & SS rRNA gene & Schindler et al. $(2001)^{16}$ \\
\hline & Mitochondrial Cox-I gene & Tham J et al. $(1999)^{23}$ \\
\hline $\begin{array}{l}\text { Reverse } \\
\text { Transcriptase } \\
\text { PCR }\end{array}$ & SS rRNA & $\begin{array}{l}\text { Li J et al. }(1995)^{24} \\
\text { Abdullah et al. }(1996)^{25} \\
\text { Ciceron et al. }(1999)^{8}\end{array}$ \\
\hline
\end{tabular}


REVIEW ARTICLE

Table R-3: Comparison of some studies using pcr for diagnosis of malaria

\begin{tabular}{|c|c|c|c|c|c|c|c|}
\hline $\begin{array}{l}\text { Author/Year of } \\
\text { publication/ } \\
\text { Place }\end{array}$ & Primer/Region coding for & $\begin{array}{l}\text { Ref. Study } \\
\text { method }\end{array}$ & $\begin{array}{l}\text { Sensi- } \\
\text { tivity }\end{array}$ & $\begin{array}{l}\text { Speci- } \\
\text { ficity }\end{array}$ & Result & Population & Implication \\
\hline $\begin{array}{l}\text { Nandwani } \\
\text { Mathur } \\
\text { 26. Delhi, India }\end{array}$ & $\begin{array}{l}\text { A set of primers for MSP1, block } \\
17 \text { (merozoite surface protein) } \\
\text { region of } P \text {. falciparum }\end{array}$ & Microscopy & $96.8 \%$ & $100 \%$ & $\begin{array}{l}310 \text { patients total, } \mathrm{Pf} \\
\text { positive } 160 .\end{array}$ & $\begin{array}{l}\text { India } \\
\text { clinically } \\
\text { patients of } \quad \text { malaria } \\
\text { coming to the malaria } \\
\text { centre, Delhi }\end{array}$ & 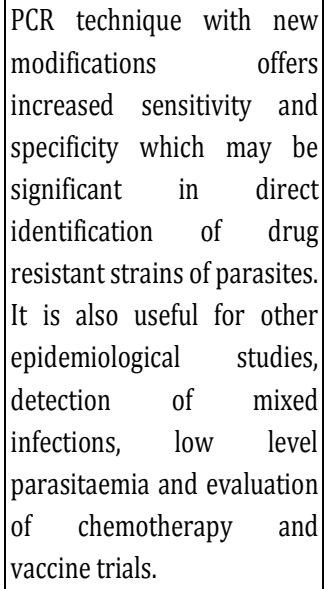 \\
\hline 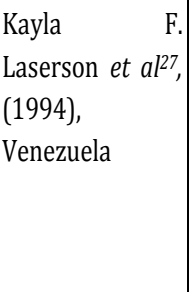 & 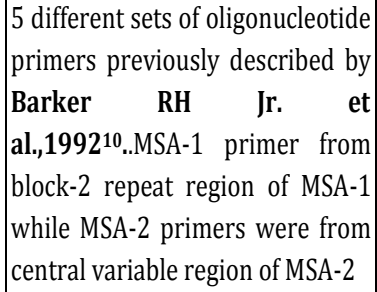 & PCR & $78 \%$ & $97 \%$ & $\begin{array}{llr}229 & \text { samples } & \text { from } \\
48 & \text { patients. } & \text { The } \\
\text { PPV/NPV of } & \text { PCR } \\
\text { methods } 8 / 95 . & \end{array}$ & $\begin{array}{l}\text { Venezuela endemic, } \\
\text { hospital based field } \\
\text { trial. }\end{array}$ & $\begin{array}{l}\text { DNA probe/PCR technology } \\
\text { can be useful tool for large- } \\
\text { scaler epidemiological } \\
\text { survey, as opposed to } \\
\text { diagnosis of acute malaria in } \\
\text { the settings of malaria } \\
\text { clinics. }\end{array}$ \\
\hline $\begin{array}{lr}\text { Tirasophon W. } \\
\text { et al28.,1994, } \\
\text { Deptt. } \\
\text { Biochemistry, } \\
\text { Mahidol } \\
\text { University, } \\
\text { Bangkok, } \\
\text { Thailand }\end{array}$ & $\begin{array}{l}\text { Pf1 and Pf2 primer for P. } \\
\text { falciparum (206bp product) } \\
\text { PV1 and PV2 primers (183 bp } \\
\text { product) } \\
\text { (Rajkulchai P.) }\end{array}$ & Microscopy & $\begin{array}{l}\text { Pf } 89 \% \\
\text { Pv91\% }\end{array}$ & $\begin{array}{l}94 \% \\
\text { (overall) }\end{array}$ & $\begin{array}{l}590 \text { individuals. PCR } \\
\text { could detect } 6 \text { mix } \\
\text { infections that were } \\
\text { characterized to be } \\
\text { single r species } \\
\text { infection by } \\
\text { microscopy. }\end{array}$ & $\begin{array}{l}\text { Thailand, endemic, } \\
\text { patients presenting to } \\
\text { malaria clinic for } \\
\text { smear examination. }\end{array}$ & $\begin{array}{l}\text { A highly sensitive, rapid (4 } \\
\text { hr) and simple method: So } \\
\text { can be used for large scale } \\
\text { epidemiological, follow up } \\
\text { drug therapy, and } \\
\text { immunization trials. }\end{array}$ \\
\hline $\begin{array}{l}\text { J.M.Rubio et } \\
\text { al29,1999,Madrid } \\
\text { Spain. }\end{array}$ & $\begin{array}{l}\text { Semi nested PCR, using four } \\
\text { species specific primers for all } \\
\text { the malaria species, targetting } \\
\text { 18S small subunit rRNA gene. }\end{array}$ & Microscopy. & 100 & 100 & $\begin{array}{|lcr|}192 & \text { whole } & \text { blood } \\
\text { and } & 71 & \text { serum } \\
\text { sample.Pf/Pm/Pv/P } \\
0, \\
68 \% / 29 \% / 14 \% / 7 \%\end{array}$ & $\begin{array}{ll}\text { Immigrants } & \text { from } \\
\text { endemic area } & \\
\end{array}$ & $\begin{array}{l}\text { Seminested PCR can be a } \\
\text { sensitive and specific tool } \\
\text { for malaria diagnosis in } \\
\text { emigrants from disease } \\
\text { endemic to non-endemic } \\
\text { region }\end{array}$ \\
\hline $\begin{array}{l}\text { Geoffrey } \\
a l^{30 ., 2002 .} \\
\text { Westmead, } \\
\text { Australia }\end{array}$ & 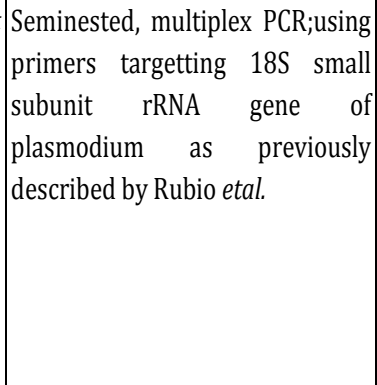 & NA & $\begin{array}{l}\text { ICT(Pf/Pv } \\
\text { j7\%/85 } \\
\% . \\
\text { 0ptimal } \\
\text { assay: } \\
\mathrm{Pf} / \mathrm{Pv} \\
85 \% / 80 \\
\%\end{array}$ & $\begin{array}{l}90 \% / 100 \\
\% \quad \text { for } \\
\mathrm{Pf} / \mathrm{Pv} \text { by } \\
\text { ICT and } \\
96 \% / 97 \\
\% \quad \text { for } \\
\text { Pf/Pv by } \\
\text { OptIMAL }\end{array}$ & 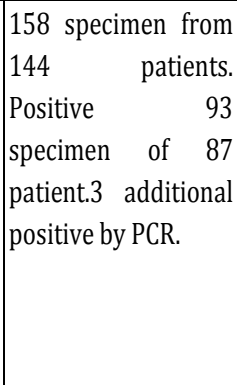 & \begin{tabular}{|l|} 
Febrile returned \\
travelers \\
from malaria endemic \\
regions.
\end{tabular} & $\begin{array}{l}\text { Despite the high sensitivity } \\
\text { of the ICT p.f/p.v assay for } P \text {. } \\
\text { falciparum malaria, caution } \\
\text { is warranted before RDT's } \\
\text { are widely adopted for the } \\
\text { diagnosis of malaria in non- } \\
\text { immune patients or in } \\
\text { countries where malaria is } \\
\text { not endemic. }\end{array}$ \\
\hline Russel & Nested PCR using primers & Microscopy & $96 \%$ & $98 \%$ & Total 8590 samples, & endemic & PCR can be used during \\
\hline
\end{tabular}




\section{REVIEW ARTICLE}

\begin{tabular}{|c|c|c|c|c|c|c|c|}
\hline $\begin{array}{l}\text { Author/ Year of } \\
\text { publication/ } \\
\text { Place }\end{array}$ & Primer/Region coding for & $\begin{array}{l}\text { Ref. Study } \\
\text { method }\end{array}$ & $\begin{array}{l}\text { Sensi- } \\
\text { tivity }\end{array}$ & $\begin{array}{l}\text { Speci- } \\
\text { ficity }\end{array}$ & Result & Population & Implication \\
\hline $\begin{array}{l}\text { Coleman et a }{ }^{31} \text {. } \\
(2002), \\
\text { Bangkok, } \\
\text { Thailand }\end{array}$ & $\begin{array}{l}\text { described by Kimura et al. }{ }^{32} \text { from } \\
\text { the small subunit ribosomal RNA } \\
\text { gene }\end{array}$ & & & & $\begin{array}{l}665 \text { positive } \mathrm{Pf} / \mathrm{Pv}, \\
265 / 386\end{array}$ & $\begin{array}{l}\text { Field based clinical } \\
\text { trial. }\end{array}$ & $\begin{array}{l}\text { active malaria surveillance } \\
\text { for malaria diagnosis though } \\
\text { its sensitivity fell at parasite } \\
\text { density }<100 / \text { microlitre in } \\
\text { this study. }\end{array}$ \\
\hline 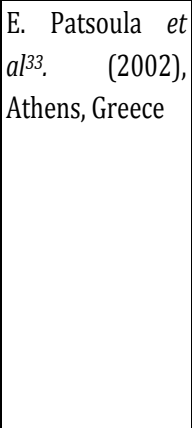 & $\begin{array}{l}\text { Simple PCR, using three primers } \\
\text { PL3 common to Pf and Pv PL4 } \\
\text { specific for Pv, PL5 specific for Pf } \\
\text { amplifying a sequence common } \\
\text { to small -subunit rRNA gene. }\end{array}$ & Microscopy & $100 \%$ & $100 \%$ & $\begin{array}{ll}124 & \text { blood sample } \\
\text { PCR } & \text { positive } 56 \\
(\mathrm{Pf} / \mathrm{Pv} ; 53 / 3)\end{array}$ & 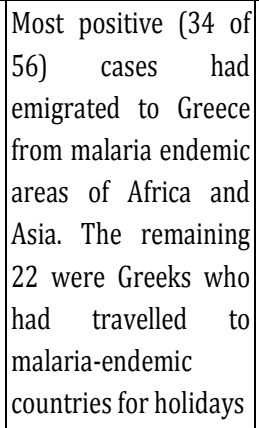 & $\begin{array}{l}\text { A simple, single step PCR } \\
\text { can be a faster method } \\
\text { which offers good sensitivity } \\
\text { and specificity, so a } \\
\text { powerful tool } \quad \text { for } \\
\text { surveillance of migrants or } \\
\text { travellers from malaria non- } \\
\text { endemic region to malaria } \\
\text { endemic regions. }\end{array}$ \\
\hline $\begin{array}{l}\text { Mathieu } \\
\text { Rougemount et } \\
\text { al }^{34} \text {. Institute of } \\
\text { Micro-biology, } \\
\text { Lausanne, } \\
\text { Switzerland }\end{array}$ & $\begin{array}{l}\text { Multiplex RT PCR using block } 9 \\
\text { region forward primer Plasmo } 1 \\
\text { and reverse primer Plasmo } 2 \text { to } \\
\text { amplify a } 157 \text { to } 165 \text { bp segment } \\
\text { of the four plasmodial } 185 \text { genes. } \\
\text { Both primer and probe } \\
\text { sequences were selected from } \\
\text { the small subunit of rRNA. }\end{array}$ & Microscopy & $\begin{array}{l}\text { All the } \\
\text { result with } \\
\text { species a } \\
\text { identified } \\
\text { favour of } \\
\text { (PCR/Prob } \\
\text { methods }\end{array}$ & $\begin{array}{l}\text { discardant } \\
\text { a regard to } \\
\text { ind genus } \\
\text { resolved in } \\
\text { molecular } \\
\text { e) }\end{array}$ & $\begin{array}{lr}86 & \text { samples. } \\
\text { blood samples } & 96 \% \\
\text { concordance } \\
\text { between } \quad \text { PCR and } \\
\text { microscopy. }\end{array}$ & $\begin{array}{l}\text { imigrants to epidemic } \\
\text { region }\end{array}$ & $\begin{array}{l}\text { A single stage multiplex PCR } \\
\text { not only permits a malarial } \\
\text { infection to be detected but } \\
\text { also allows speciation in } \\
\text { cases of mixed infection and } \\
\text { monitoring patient on } \\
\text { antimalarial therapy. }\end{array}$ \\
\hline 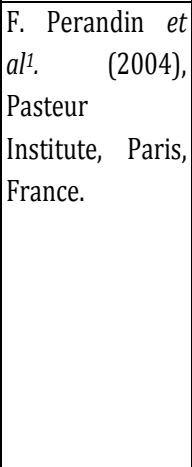 & $\begin{array}{l}\text { Nested PCR using previously } \\
\text { used genus specific primers by } \\
\text { Snounou et al }{ }^{6} \text {. RTPCR for Pf, Pv } \\
\text { and Po using sequence quoted by } \\
\text { Snounou et al. }{ }^{6} \text { to specifically } \\
\text { amplify } 18 \mathrm{~S} \text { rRNA gene }\end{array}$ & Nested PCR & $100 \%$ & $100 \%$ & $\begin{array}{l}122 \text { whole blood } \\
\text { sample, } \\
\text { retrospective } \\
60 \text { study, } \\
\text { negativer All } \quad \text { the } \\
\text { mixed infection and } \\
\text { correctrriver species } \\
\text { identification } \quad \text { were } \\
\text { done by RT PCR }\end{array}$ & $\begin{array}{l}\text { Travellers to endemic } \\
\text { regions }\end{array}$ & $\begin{array}{l}\text { RT PCR picked up mixed } \\
\text { infection and it is faster, } \\
\text { sensitive alternative to } \\
\text { nested PCR and minimizes } \\
\text { risk of contamination in post } \\
\text { PCR processing so can be } \\
\text { implemented in routine } \\
\text { diagnostic malaria test once } \\
\text { further studies confirm } \\
\text { clinical value of this } \\
\text { technique. }\end{array}$ \\
\hline \begin{tabular}{|l} 
Gabriella \\
Farcas et $a l^{2}$. \\
(2004); Toronto, \\
Canada
\end{tabular} & $\begin{array}{l}\text { RT PCR, using primers designed } \\
\text { for } 18 \mathrm{~S} \text { rRNA gene, for all malaria } \\
\text { species }\end{array}$ & Nested PCR & $99.5 \%$ & $00 \%$ & 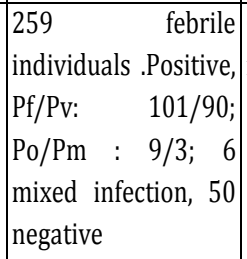 & $\begin{array}{lr}\text { Canada, } & \text { travelers } \\
\text { from endemic regions. }\end{array}$ & $\begin{array}{l}\text { RT PCR is rapid }(245 \mathrm{~min}), \\
\text { sensitive and specific } \\
\text { method for detection of } \\
\text { malaria in returned } \\
\text { travelers. }\end{array}$ \\
\hline 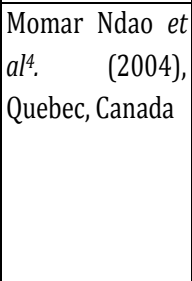 & $\begin{array}{l}\text { Nested PCR using primers } \\
\text { designed by Snounou et al. for } \\
\text { 18S ribosomal subunit of all four } \\
\text { malaria parasite }\end{array}$ & Nested PCR & \begin{tabular}{|l|}
$50 \%$ \\
Microscop \\
$y$ \\
$37.5 \%$ ICT \\
$29.1 \%$
\end{tabular} & 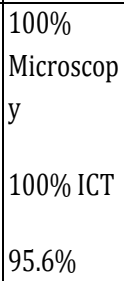 & $\begin{array}{l}\text { Positive } 98 \text { of } 521 \\
\text { out of which } 81 \text { are } \\
\text { Pf rest other species. }\end{array}$ & \begin{tabular}{|lr} 
Refugee in & Quebec \\
and Canada & from \\
Tanzania Camp &
\end{tabular} & $\begin{array}{l}\text { PCR is by far the most } \\
\text { powerful tool for } \\
\text { surveillance of migrant } \\
\text { population and mitigate } \\
\text { against transmission to the } \\
\text { host population. }\end{array}$ \\
\hline
\end{tabular}


REVIEW ARTICLE

\begin{tabular}{|c|c|c|c|c|c|c|c|}
\hline $\begin{array}{l}\text { Author/ Year of } \\
\text { publication/ } \\
\text { Place }\end{array}$ & Primer/Region coding for & $\begin{array}{l}\text { Ref. Study } \\
\text { method }\end{array}$ & $\begin{array}{l}\text { Sensi- } \\
\text { tivity }\end{array}$ & $\begin{array}{l}\text { Speci- } \\
\text { ficity }\end{array}$ & Result & Population & Implication \\
\hline & & & Optimal & Optimal & & & \\
\hline $\begin{array}{l}\text { Stephanine } \\
\text { Johnston et } \\
\text { Jl3. } \\
\text { (2006), Atlanta, } \\
\text { Georgia }\end{array}$ & $\begin{array}{l}\text { Nested PCR assay, using } \\
\text { modification of technique } \\
\text { described by Snounou et al }{ }^{6} \text {. with } \\
\text { primers targeting all the } \\
\text { Plasmodium species } 18 \mathrm{~S} \text { rRNA } \\
\text { genes }\end{array}$ & \begin{tabular}{|lr} 
Nested & PCR \\
$($ Snowon & et \\
al6.) & \\
&
\end{tabular} & $93.3 \%$ & $100 \%$ & 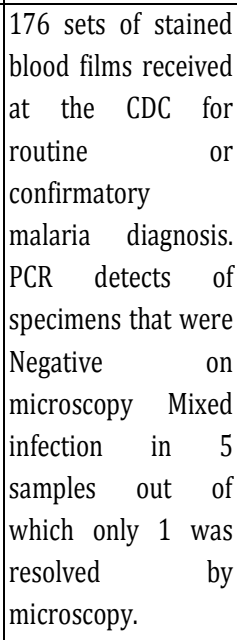 & $\begin{array}{l}\text { Travellers to malaria } \\
\text { endemic regions }\end{array}$ & \begin{tabular}{lll|} 
Nested & PCR & was more \\
sensitive & than & microscopy, \\
allowing & P.falciparum \\
detection in cases of low \\
parasitemias, as well as \\
mixed infections.
\end{tabular} \\
\hline $\begin{array}{l}\text { S. Gatti et } \\
\text { al35.2007 } \\
\text { Laboratory of } \\
\text { Parasitology, } \\
\text { Virology, Pavia, } \\
\text { Italy }\end{array}$ & $\begin{array}{l}\text { Conventional PCR using five } \\
\text { conventional kits. } \\
\text { AMS61, AMS42, AMS43, AMS44, } \\
\text { AMS45, Clorit sub Milano Italy } \\
\text { based on } 185 \text { ribosomal RNA } \\
\text { gene of parasite for different } \\
\text { plasmodium species. AM61 is } \\
\text { panspecific (other than P. } \\
\text { falciparum) while rest are species } \\
\text { specific kits. }\end{array}$ & Microscopy & \begin{tabular}{|l} 
ICT - Now \\
malaria \\
$100 \%$ for \\
Pf \\
AMS61 \\
Assay \\
$91.0 \%$ for \\
all \\
malarial \\
infection
\end{tabular} & $\begin{array}{l}100 \% \text { for } \\
\mathrm{Pf} \\
98.2 \% \text { all } \\
\text { malarial } \\
\text { infection }\end{array}$ & $\begin{array}{ll}306 \text { subjects: } & 171 \\
\text { Italians and } & 135 \\
\text { non-European. } & \end{array}$ & $\begin{array}{|lr|}\text { European } & \text { and } \\
\text { migrants } & \text { from } \\
\text { malaria } & \text { endemic } \\
\text { countries. } & \\
\end{array}$ & $\begin{array}{l}\text { Compared with the } \\
\text { microscopy both } \text { ICT } \text { and } \\
\text { PCR-based assays were poor } \\
\text { at identifying mixed } \\
\text { infections. }\end{array}$ \\
\hline 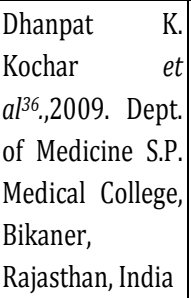 & $\begin{array}{l}\text { Primers for } 18 \mathrm{~S} \text { ribosomal RNA } \\
\text { gene of Plasmodium and used, } 1 \\
\text { genus specific } \quad 5^{\prime} \text { primer, } 2 \\
\text { species specific 3' primer in same } \\
\text { reaction mixture. }\end{array}$ & Microscopy & N.A. & NA & $\begin{array}{ll}1091 & \text { patients } \\
635 / 456 ; & \mathrm{Pf} / \mathrm{Pv}\end{array}$ & $\begin{array}{l}\text { India, endemic, adult } \\
\text { clinically suspected } \\
\text { patients of malaria } \\
\text { admitted to medicine } \\
\text { ward of the study } \\
\text { hospital included. }\end{array}$ & $\begin{array}{lrr}\text { PCR as a } & \text { useful } & \text { tool to } \\
\text { diagnose } & \text { severe } & \text { P.vivax } \\
\text { malaria. } & & \end{array}$ \\
\hline
\end{tabular}

Abstracts of some studies on comparing pcr with microscopy and rapid diagnostic tests (rdt) suggesting advantages and limitations

In a study titled "Limited level of accuracy provided by available rapid diagnosis tests for malaria enhances the need for PCR-based reference laboratories" conducted by JM. Rubio et al ${ }^{37}$., in 2001, at Department of Microbiology and Department of Infectious Diseases, Madrid, Spain .The author's data suggest that the accuracy of RDT's is insufficient and could increase the number of incorrect malaria diagnoses. RDT's could help the initial assessment of malaria in returned travellers and migrants, but there is a need to develop more specialized laboratories with available 
confirmatory diagnostic techniques (PCR). The main difficulty still encountered by the use of RDT's is the correct identification of plasmodium species.

In another study in Department of Medicine, Toronto Canada David C. Richardson, et $\mathrm{al}^{38}$. evaluated the performance of one rapid non-microscopic antigen detection assay, the Makromed dipstick test, blindly compared to PCR and microscopy for the diagnosis of Plasmodium falciparum malaria in 200 febrile returned travellers. The Makromed assay detects the presence of P. falciparum-specific histidine-rich protein II with an antigen capture immunochromatographic strip format. Compared to PCR as the reference standard, the dipstick assay had a sensitivity of $97.0 \%$ and a specificity of $96.0 \%$. The positive and negative predictive values were $81.2 \%$ and $99.5 \%$, respectively (Journal of Clinical Microbiology, Dec. 2002, p. 4528-4530).

In a study conducted by Jamshaid Iqbal et $\mathrm{al}^{39}$., in 2002 in Department of Microbiology, Faculty of Medicine, Kuwait University, and Malaria Laboratory, Department of Community Health, Ministry of Health, Safat, Kuwait titled "Comparison of the OptiMAL test with PCR for the detection of Plasmodium falciparum and Plasmodium vivax infection diagnosis of malaria in immigrants from endemic tropical countries" using microscopy and a PCR as reference standards in 550 immigrants who presented with fever The PCR and species identification were performed as described by Hang et $\mathrm{al}^{40}$. with slight modifications. Oligonucleotide primers which amplify a 206-bp sequence were used for P. falciparum, and primers which amplify a 131-bp sequence from the gene for the small subunit of rRNA were used for P. vivax. The study concluded that the sensitivity and specificity of the optimal test are comparable to those of microscopy in detecting malaria infection at a parasitemia level of $>100$ parasites $/ \mathrm{ml}$; however, the test failed to identify more than half of the patients with a Parasitemia level of $<50$ parasites/ml. Thus, the optimal test should be used with great caution, and it should not replace conventional microscopy in the diagnosis of malaria infection.

Kathleen J. et $\mathrm{al}^{41}$., in a study titled, "Evaluation of a colorimetric PCR-based assay to diagnose Plasmodium falciparum malaria in travelers", conducted in tropical disease unit, division of infectious diseases, Department of Medicine, Toronto Hospital, Canada. The authors performed a blinded evaluation of a non isotopic colorimetric PCR based assay (Digene sharp signal system) and compared the results with those obtained by microscopy and nested PCR for the detection of the P. falciparum malaria in 150 febrile travelers. Patients presenting to the tropical disease unit of the Toronto Hospital from June 1995 to July 1997. A nested PCR method for the amplification of a fragment of the plasmodial small-subunit rRNA gene was performed as described previously by Snounou et al.6. The sensitivity and specificity of the Digene kit for the diagnosis of Plasmodium falciparum infection were calculated by using nested PCR-based species identification as the reference standard. The colorimetric assay had a sensitivity of $100 \%$ and a specificity of $95.4 \%$ for the detection of Plasmodium falciparum. This PCR based non-isotopic assay is a rapid, sensitive, and specific method for the detection of $\mathrm{P}$. falciparum malaria in returned travelers. It may be particularly useful for the identification of $P$. falciparum in patients with mixed infections or in patients with low circulating levels of parasitemia, for whom reliable species determination by microscopy is not always possible. A limitation of this test is that only falciparum malaria is detected; however, it may be combined with a similar assay for the diagnosis of P. vivax malaria.

A study titled "Development of a PCR assay followed by nonradioactive hybridization using oligonucleotides covalently bound to Covalink $\mathrm{NH}$ microwell for detection of four plasmodium 
species in blood samples from humans" published in journal of clinical microbiology, Sept. 2006 conducted by M. Machouart et $\mathrm{al}^{42}$. The authors developed and evaluated a PCR-based assay to detect four Plasmodium species in 79 blood samples from 56 travelers returning from areas where malaria is endemic (for some patients, several blood samples were collected during the first days of the hospitalization period) and presenting suggestive clinical features were collected in parasitology-mycology laboratories of hospitals in Nancy and Tourcoing (France). DNA amplification targeting a small region of the 18S-rRNA gene was performed with Plasmodium genus-specific primers. The biotinylated PCR products were then identified by PCR-colorimetric Covalink NH microwell plate hybridization (CMPH), using species-specific phosphorylated probes covalently bound to a pretreated polystyrene surface. The results from PCR-CMPH showed high specificity, and for 47 of the 56 patients (84\%), microscopy and PCR-CMPH results were in agreement. Discordant results were reevaluated with microscopy examination, other molecular methods, and DNA sequencing. Except for one patient, discrepancies were resolved in favor of PCRCMPH. Three mixed infections were detected, four species identification errors were corrected and two negative results were shown to be positive. The study results indicate that PCR-CMPH is a simple, rapid, and specific method for malaria diagnosis. It employs stable reagents and inexpensive equipment, making it suitable for routine epidemiological use. (Journal of Clinical Microbiology, Sept. 2006, p. 3279-3284 Vol. 44, No. 9).

In a study titled "Real-Time PCR for detection and identification of Plasmodium spp.", conducted by Kathy A. Mangold et al ${ }^{43}$., at Department of Pathology and Laboratory Medicine, Evanston Northwestern Health-Care, Evanston, published in Journal of Clinical Microbiology, May 2005, the authors developed and used a Real-Time PCR assay to detect and distinguish four Plasmodium spp that cause human disease, by using a single amplification reaction and melting curve analysis. For assay validation, 358 patient blood samples from the national university hospital in Singapore and Evanston Northwestern Healthcare in Illinois were analyzed. Consensus primers were used to amplify a species-specific region of the multicopy $18 \mathrm{~S}$ rRNA gene, and SYBR green was used for detection in a light-cycler instrument. Patient specimens infected at 0.01 to $0.02 \%$ parasitemia densities were detected, and analytical sensitivity was estimated to be 0.2 genome equivalent per reaction. Melting curve analysis based on nucleotide variations within the amplicons provided a basis for accurate differentiation of Plasmodium falciparum, P. vivax, P. ovale, and P. malariae. Of 76 blinded patient samples with a microscopic diagnosis of P. falciparum, P. vivax, or P. ovale infection, 74 (97.4\%) were detected by Real time PCR including three specimens containing mixed P. falciparum-P. vivax infections. Real-time PCR with melting curve analysis could be a rapid and objective supplement to the examination of Giemsa-stained blood smears and may replace microscopy following further validation.

In a study titled "Evaluation of Real-Time PCR FRET assay for rapid detection and differentiation of plasmodium species in returning traveller's and migrants" conducted by Innocent Safeukui et $\mathrm{al}^{44}$. at travel clinic and imported diseases units, department of internal medicine, university hospital centre, France published in Malaria journal 2008, the authors collected a total of 119 blood samples in EDTA tube from traveller's or migrants admitted to the Saint André university hospital in Bordeaux, with suspected clinical malaria from years 2000 to 2006.The primers and probes were designed using the multicopy, stable and highly conserved 18S rRNA gene single-stranded sequences of plasmodium species available from genbank. The sequence of the 
acceptor FRET hybridization probe was designed on the basis of one nucleotide mismatch difference that distinguish the 18S rRNA gene of the P. falciparum from those of the three other plasmodium species.The P.falciparum specific primers were designed to amplify a 120-bp region from the cytochrome c-oxidase subunit 1 (cox-1) mitochondrial gene. A rapid FRET Real time PCR, using one set of primer and probe for the diagnosis of Plasmodium spin febrile returning traveller's and migrants was described. An important advantage of this approach is the higher sensitivity and specificity for the detection of Plasmodium sp. and to differentiate P. falciparum from the three other malaria parasite species (P. vivax, P. malariae and P. ovale) based on the melting. Concurrently to microscopic examination, such results can be used to ensure rapid treatment administration and proper follow-up of the malaria attacks by the practitioner.

Conclusion: Although there have been many previous publication on the detection of malaria and identification of plasmodium species by PCR, all relates either to the use of some form of nested PCR, using nested or heminested primers (Snounou et al6., 1993a,b; Rubio et al ${ }^{37}$., 1999; Gal et al. ${ }^{45}$, 2001), or to the detection of amplified DNA using labeled, specific probes or ELISA (Laoboonchai et al.46, 2001), for species identification. Single round PCR has only been used alone to detect a particular species, usually P. falciparum (Tham et al23., 1999; Barker et al10., 1994; Hang et al ${ }^{40 .}$., 1995), or simply to detect malarial infection without species identification (Ciceron et al. ${ }^{8}, 1999$ ). The method is relatively quick, compared to nested and hemi-nested PCR, and can be completed within $3 \mathrm{~h}$ of sample receipt (Patsoula $\mathrm{E}$ et $\left.\mathrm{al}^{33}, 2003\right)$. Thus, a same day diagnosis of malaria could be provided, and the assay would clearly be useful in a reference-laboratory setting at a center where majority of the patients are of complicated malaria, have already taken antimalarial treatment on clinical suspicion prior to being investigated at the referral center laboratory . The risks of cross contamination, which could be a problem with assays based on nested PCR unless suitable, stringent precautions are observed, is relatively low for single-round assays. The test could provide a powerful back-up to the to blood smear examination (which is still far from redundant and is not replaced by this technique.) and should prove very useful in detection of parasitaemias which is too low to be detected in blood smears (Babiker et al. ${ }^{47}, 1999$ ).

ACKNOWLEDGEMENT: This review in part is supported by Dr. Vimala Venkatesh and Dr. Mastan Singh, Post Graduate Department of Microbiology, King George’s Medical University, Lucknow, U.P., India.

\section{BIBLIOGRAPHY:}

1. F. Perandin, N. Manca, A. Calderaro, G. Piccolo, L. Galati, L. Ricci, M. C. Medici, M. C. Arcangeletti, G. Snounou, G. Dettori, and C. Chezzi. Development of a Real-Time PCR Assay for Detection of Plasmodium falciparum, Plasmodium vivax, and Plasmodium ovale for Routine Clinical Diagnosis. J. Clin. Microbiol. 2004 42: 1214-1219.

2. Gabriella A. Farcas, Kathleen J. Y. Zhong, Tony Mazzulli, and Kevin C. Kain. Evaluation of the Real Art Malaria LC Real-Time PCR Assay for Malaria Diagnosis. J. Clin. Microbiol. 2004 42: 636-638.

3. Stephanie P. Johnston, Norman J. Pieniazek, Maniphet V. Xayavong, Susan B. Slemenda, Patricia P. Wilkins, and Alexandre J. da Silva. PCR as a Confirmatory Technique for Laboratory Diagnosis of Malaria. J. Clin. Microbiol. 2006 44: 1087-1089. 
4. Momar Ndao, Etienne Bandyayera, Evelyne Kokoskin, Theresa W. Gyorkos, J. Dick. MacLean, and Brian J. Ward. Comparison of Blood Smear, Antigen Detection, and Nested-PCR Methods for Screening Refugees from Regions Where Malaria Is Endemic after a Malaria Outbreak in Quebec, Canada. J. Clin. Microbiol. 2004 42: 2694-2700.

5. Brown, A. E., K. C. Kain, J. Pipithkul, and H. K. Webster. 1992. Demonstration by the polymerase chain reaction of mixed Plasmodium falciparam and $\mathrm{P}$. vivax infections under detected by conventional microscopy. Trans. R. Soc. Trop. med. Hyg. 86:609-612.

6. Snounou, G., S. Viriyakosol, W. Jarra, S. Thaithong, and K.N. Brown. 1993. Identification of the four human malaria parasite species in field samples by the polymerase chain reaction and detection of a high prevalence of mixed infections. Mol. Biochem. Parasitol. 58:283-292.

7. Klement, E., M. P. Chauveheid, M. Thellier, F. Bricaire, M. Danis, and E. Caumes. 2001. Subacute clinical forms of Plasmodium falciparum malaria in travelers receiving chloroquine-proguanil prophylaxis. Clin. Infect. Dis. 33: e1-e2.

8. Ciceron, L., G. Jaureguiberry, F. Gay, and M. Danis. 1999. Development of a Plasmodium PCR for monitoring efficacy of antimalarial treatment. J. Clin. Microbiol. 37:35-38.

9. Humar, A., M. A. Harrington, and K. C. Kain. 1997. Evaluation of a non-isotopic polymerase chain reaction-based assay to detect and predict treatment failure of Plasmodium vivax malaria in traveller's. Trans. R. Soc. Trop. Med. Hyg. 91: 406-409.

10. Barker RH Jr, Banchongaksorn T, Courval JM, Suwonkerd W, Rimwungtragoon K, Wirth DF: A simple method to detect Plasmodium falciparum directly from blood samples using the polymerase chain reaction. Am J Trop Med Hyg 1992, 46:416-426.

11. Haditsch M. (2004). Quality and reliability of current malaria diagnostic methods. Travel Med \& Infect Dis. 2:149-160.

12. Frazen L, Westin G, Shabo R, Aslund L, Perlmann H, Persson T, Wigzell H, Pettersson U.(1984). Analysis of clinical specimens by hybridization with probe containing repentive DNA from P. falciparum. Lancet 1:525-527.

13. McCutchan, T. F., V. F. de la Cruz, A. A. Lal, J. H. Gunderson, H. J. Elwood, and M. L. Sogin. 1988. Primary sequences of two small subunit ribosomal RNA genes from Plasmodium falciparum. Mol. Biochem. Parasitol. 28:63-68.

14. Das, A., B. Holloway, W. E. Collins, V. P. Shama, S. K. Ghosh, S. Sinha, S.E. Hasnain, G.P. Talwar, and A. A. Lal. 1995. Species-specific 18S rRNA gene amplification for the detection of P. falciparum and P. vivax malaria parasites. Mol. Cell. Probes 9: 161-165.

15. Kawamoto, F., H. Miyake, O. Kaneko, M. Kimura, T.D. Nguyen, Q. Liu, M. Zhou, D.D. Le, S. Kawai, S. Isomura and Y. Wataya. 1996. Sequence variation in the $18 \mathrm{~S}$ rRNA gene, a target for PCRbased malaria diagnosis, in Plasmodium ovale from southern Vietnam. J. Clin. Microbiol. 34:2287-2289.

16. Schindler, H.C., L. Montenegro, R. Montenegro, A.B. Carvalho, F.G. Abath, and G. Jaureguiberry. 2001. Development and optimization of polymerase chain reaction-based malaria diagnostic methods and their comparison with quantitative buffy coat assay. Am. J. Trop. Med. Hyg. 65: 355-361.

17. Witney AA, Doolan DL, Anthony RM, Weiss WR, Hoffman SL, Carucci DJ: Determining liver stage parasite burden by real time quantitative PCR as a method for evaluating pre-erythrocytic malaria vaccine efficacy. Mol Biochem Parasitol 2001, 118:233-245. 
18. Zhong. K.J. and K.C. Kain. 1999. Evaluation of a colorimetric PCR-based assay to diagnose Plasmodium falciparum malaria in travelers. J. Clin. Microbiol. 37: 339-341.

19. Sethabur, O., A. E. Brown, S. Panyim, K. C. Kain, H. K. Webster, and P. Echeverria. 1992. Detection of Plasmodium falciparum by polymerase chain reaction in a field study. J. Infect. Dis. 166: 145-148.

20. Kain, K.C. and D.E. Lanar. 1991. Determination of genetic variation within Plasmodium falciparum by using enzymatically amplified DNA from filter paper disks impregnated with whole blood. J. Clin. Microbiol. 29:1171-1174.

21. Edoh, D., S. Steiger, B. Genton, and H.P. Beck. 1997. PCR amplification of DNA from malaria parasites on fixed and stained thick and thin blood films. Trans. R. Soc. Trop. Med. Hyg. 91:361363.

22. Eoley, M., L. C. Ranford-Cartwright, and H.A. Babiker. 1992. Rapid and simple method for isolating malaria DNA from fingerprick samples of blood. Mol. Biochem. Parasitol.53: 241-244.

23. Tham, J. M., S. H. Lee, T. M. Tan. R. C. Ting, and U. A. Kara, 1999. Detection and species determination of malaria parasites by PCR: comparison with microscopy and with ParaSight -F and ICT malaria Pf tests in a clinical environment. J. Clin. Microbiol. 37:1269-1273.

24. Li, J., R. A. Wirtz, G. A. McConkey, J. Sattabongkot, A.P. Waters, M.J. Rogers, and T.F. McCutchan. 1995. Plasmodium: genus-conserved primers for species identification and quantitation. Exp. Parasitol. 81: 182-190.

25. Abdullah, N. R., T. Furuta, R. Taib, K. Kita, S. Kojima, and M. J. Wah. 1996. Short report: development of a new diagnostic method for Plasmodium falciparum infection using a reverse transcriptase-polymerase chain reaction. Am. J. Trop. Med. Hyg. 54: 162-163.

26. Nandwani S, Mathur M, Rawat S. Evaluation of the polymerase chain reaction analysis for diagnosis of falciparum malaria in Delhi, India. Indian J Med Microbiol 2005; 23:176-8.

27. Kayla F. Laserson, Izaskun Petralanda, Daniel M.Hamlin, Raquel Almera, Manuel Fuentes, Anibal Carrasquel, and Robert H. Barker Jr. Use of the polymerase chain reaction to directly detect malaria parasites in blood samples from the Venezuelan Amazon. Am J Trop Med Hyg., 50(2), 1994, pp. 169-180.

28. Tirasophon $\mathrm{W}$, Rajkulchai $\mathrm{P}$, et al. A highly sensitive, rapid and simple polymerase chain reaction-based method to detect human malaria (P. falciparum and P. vivax) in blood samples. Am J Trop Med Hyg 1993; 87: 647-8.

29. Rubio JM, Benito A, Berzosa PJ, Roche J, Puente S, Subirats M, Lopez- Velez R, Garcia L, Alvar J: Usefulness of seminested multiplex PCR in surveillance of imported malaria in Spain. J Clin Microbiol 1999, 37:3260-3264.

30. E. Geoffrey Playford and John Walker Evaluation of the ICT Malaria P.f/P.v and the OptiMal Rapid Diagnostic Tests for Malaria in Febrile Returned Travellers. J. Clin. Microbiol., Nov 2002; 40: 4166 - 4171 .

31. Russell E Coleman, Jetsumon Sattabongkot, Sommai Promstaporm, Nongnuj Maneechai1, Bousaraporn Tippayachai, Ampornpan Kengluecha, Nattawan Rachapaew, Gabriela Zollner, Robert Scott Miller, Jefferson A Vaughan, Krongtong Thimasarn and Benjawan Khuntirat Comparison of PCR and microscopy for the detection of asymptomatic malaria in a Plasmodium falciparum/vivax endemic area in Thailand, Malaria Journal 2006, 5:121 doi: 10.1186/14752875-5-121. 
32. Kimura M, Kaneko O, Qing L, Mian Z, Kawamoto F, Wataya Y, Otani S, Yamaguchi Y, Tanabe K: Identification of the four species of human PCR diagnosis for four human malaria parasites. The Toyota Foundation Mini-Symposium on Malaria, Faculty of Tropical.

33. Patsoula E, Spanakos G, Sofianatou D, Parara M, Vakalis NC: A single- step, PCR-based method for the detection and differentiation of Plasmodium vivax and P. falciparum. Ann Trop Med Parasitol 2003, 97:15-21.

34. Mathieu Rougemont, Madeleine Van Saanen, Roland Sahli, Hans Peter Hinrikson, Jacques Bille, and Katia Jaton. Detection of Four Plasmodium Species in Blood from Humans by 18S rRNA Gene Subunit-Based and Species-Specific Real-Time PCR Assays. J. Clin. Microbiol. 2004 42: 5636-5643.

35. S. Gatti, M.Gramegna, Z.Bisoffi, A. Raglio, M. Gulletta, C. Klersy, A. Bruno, R. Maserati, S. Madama, M. Scaglia, and The GISPI Study Group. A Comparison of three diagnostic techniques for malaria: a rapid diagnostic test (NOW Malaria), PCR and microscopy. Annals of tropical Medicine \& parasitology, Vol. 101, No. 3, 195-204 (2007).

36. Dhanpat K. Kochar, Ashish Das, Sanjay K. Kochar, Vishal Saxena, Parmendra Sirohi, Shilpi Garg, Abhishek Kochar, Mahesh P. Khatri, and Vikas Gupta Severe Plasmodium vivax Malaria: A Report on Serial Cases from Bikaner in Northwestern India. Am J Trop Med Hyg, Feb 2009; 80: 194- 198.

37. J.M. Rubio, I. Buhigas, M. Subirats, M. Baquero, S. Puente, and A. Benito Limited Level of Accuracy Provided by Available Rapid Diagnosis Tests for Malaria Enhances the Need for PCRBased Reference Laboratories. J. Clin. Microbiol, Jul 2001; 39: 2736 - 2737.

38. David C. Richardson, Michele Ciach, Kathleen J. Y. Zhong, Ian Crandall, and Kevin C. Kain. Evaluation of the Makromed Dipstick Assay versus PCR for Diagnosis of Plasmodium falciparum Malaria in Returned Travelers. J. Clin. Microbiol, Dec 2002; 40: 4528 - 4530.

39. Iqbal J, Muneer A, Khalid N, Ahmed MA, 2003. Performance of the OptiMAL test for malaria diagnosis among suspected malaria patients at the rural health centers. Am J Trop Med Hyg 68: 624-62.

40. Hang, V. T., Be, T.V., Tran, P.N., Thanh, L.T., Hien, L.V., O’brine, E. \& Morris, G.E. (1995). Screening donor blood for malaria by polymerase chain reaction. Transactions of the Royal Society of Tropical Medicine and Hygiene, 89, 44-47.

41. Kathleen J. Y. Zhong, Carola J. Salas, Robyn Shafer, Alex Gubanov, Robert A. Gasser, Jr., Alan J. Magill, J. Russ Forney, and Kevin C. Kain. Comparison of IsoCode STIX and FTA Gene Guard Collection Matrices as Whole-Blood Storage and Processing Devices for Diagnosis of Malaria by PCR. J. Clin. Microbiol, Mar 2001; 39: 1195 - 1196.

42. M. Machouart, L. Bigois-Delemotte, F. Ajana, M. Brizion, M. F. Biava, J. Collomb, and B. Fortier. Development of a PCR Assay Followed by Nonradioactive Hybridization Using Oligonucleotides Covalently Bound to CovaLink NH Microwells for Detection of Four Plasmodium Species in Blood Samples from Humans. J. Clin. Microbiol. 2006 44: 3279-3284.

43. Kathy A. Mangold, Rebecca U. Manson, Evelyn S. C. Koay, Lindsey Stephens, MaryAnn Regner, Richard B. Thomson, Jr., Lance R. Peterson, and Karen L. Kaul. Real-Time PCR for Detection and Identification of Plasmodium spp. J. Clin. Microbiol. 2005 43: 2435-2440.

44. Innocent Safeukui, Pascal Millet, Sébastien Boucher, Laurence Melinard, Frédéric Fregeville, Marie-Catherine Receveur, Thierry Pistone, Pierre Fialon, Philippe Vincendeau, Hervé Fleury 
and Denis Malvy. Evaluation of FRET real-time PCR assay for rapid detection and differentiation of Plasmodium species in returning traveller's and migrants. Malaria Journal 2008, 7:70 doi: 10.1186/1475-2875-7-70.

45. Gal S., Fidler, C., Turner, S., Lo, Y.M., Roberts, D.J. \& Wainscoat, J.S. (2001). Detection of Palsmodium falciparum DNA is plasma. Annals of the New York Academy of Sciences, 945, 234238.

46. LaoBonchai, A. Kawamoto, F., Thanoosingha, N., Kojima, S., Scott Miller, R.R., Kain, K.C. \& Wongsrichanalai, C. (2001). PCR-based ELISA technique for malaria diagnosis of specimens from Thailand. Tropical Medicine and International Health, 6, 458-462.

47. Babiker, H.A., Abdel-Wahab, A., Ahmd, S., Soleiman, S., Ranford-Cartwright, L., Carter, R. \& Walliker, D. (1999). Detection of low level Plasmodium falciparum gametocytes using reverse transcriptase polymerase chain reaction. Molecular and Biochemical Parasitology. 99, 143-148.

\section{AUTHORS:}

1. Snehanshu Shukla

2. Harshita Pant

\section{PARTICULARS OF CONTRIBUTORS:}

1. Assistant Professor, Department of Microbiology, Mayo Institute of Medical Sciences",Barabanki, Lucknow.

2. Assistant Professor, Department of Radiodiagnosis, Mayo Institute of Medical Sciences",Barabanki, Lucknow.

\section{NAME ADRRESS EMAIL ID OF THE} CORRESPONDING AUTHOR:

Dr. Snehanshu Shukla,

Plot-1, Basant vihar Colony,

Behind St. Mary's Inter College, Sect.14, Indira Nagar, Lucknow, U.P- 226016.

E-mail: shuklasnehanshu@gmail.com

Date of Submission: 01/07/2013.

Date of Peer Review: 01/07/2013.

Date of Acceptance: 03/07/2013.

Date of Publishing: 15/07/2013 